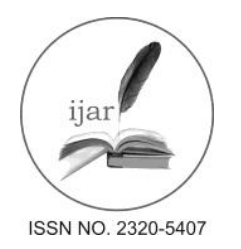

\section{Journal homepage:http://www.journalijar.com Journal DOI:10.21474/IJAR01}

\section{RESEARCH ARTICLE}

INTERNATIONAL JOURNAL

OF ADVANCED RESEARCH

OH+1,

\title{
Length-weight relationship, Condition factor, Sex ratio, Gonadal Somatic Index and Size at Maturity of Omena, Rastrineobola argentea (Pellegrin, 1904) in Lake Victoria, Kenya.
}

\author{
${ }^{* 1}$ Yongo, E., ${ }^{1}$ Manyala, J.O., ${ }^{2}$ Njiru, J.M., ${ }^{3}$ Outa, N.O., ${ }^{4}$ Kito, K., ${ }^{4}$ Matsushita,Y. \\ 1. University of Eldoret, Department of Fisheries and Aquatic Sciences, P.O Box 1125-30100, Eldoret, Kenya. \\ 2. Kisii University, Department of Applied \& Fisheries Sciences, P.O Box 408-40200, Kisii, Kenya. \\ 3. LAVICORDProject-Maseno University, P.O. Box 3105-40100, Kisumu, Kenya. \\ 4. Nagasaki University, Graduate School of Fisheries and Environmental Sciences, 1-14 Bunkyo-machi, \\ Nagasaki-shi, Nagasaki 852-8521, Japan.
}

\section{Manuscript Info ABSTRACT}

\section{Manuscript History:}

Received: 10 April 2016

Final Accepted: 15 May 2016

Published Online: June 2016

Key words:

Omena, maturity, condition factor, sex ratio.

*Corresponding Author

Edwine Yongo
The present study investigated on Length-weight relationship, Condition factor, Sex ratio, Gonadal Somatic Index (GSI) and Size at Maturity of Omena Rastrineobola argentea. Samples (2240 fish) were collected monthly between August 2014 and March 2015 in the Kenyan waters of Lake Victoria. Results for length-weight relationship revealed that $R$. argentea experienced positive allometric growth $(b>3)$. The regression slope $b$ was significantly different between the sexes (ANCOVA: $\mathrm{F}=18.13, \mathrm{p}=0.001$ ) and within the stations (ANCOVA: $\mathrm{F}=10.23$, $\mathrm{p}=0.032$ ). The fish population was dominated by females with an overall male to female ratio of 1.00:1.38. The highest length at $50 \%$ maturity $\left(\mathrm{L}_{\mathrm{M} 50}\right)$ was recorded in male fish $(39.8 \mathrm{~mm}$ $\mathrm{SL})$ and the lowest in female fish $(35.7 \mathrm{~mm} \mathrm{SL})$. The mean $( \pm \mathrm{SE})$ condition values recorded were $1.096 \pm 0.01$ in males and $1.097 \pm 0.01$ in females with range values of $0.78-1.59$ and $0.77-1.57$ respectively. The condition factor did not differ significantly between male and female fish (Kruskal Wallis test; $\mathrm{H}=0.03, \mathrm{p}=0.86)$. The mean $( \pm \mathrm{SE})$ Gonadal Somatic Index (GSI) recorded were $1.08 \pm 0.04$ (male) and $6.02 \pm 0.14$ (female) with range values of 0.02-3.38 and 0.34-17.39 in male and female fish respectively. $R$. argentea showed peak condition and GSI in September/February and October/March for open waters and Nyanza Gulf respectively. Studies on this fish should therefore not assume isometric growthpattern. The fish has reduced in length at maturity, thus the fisheries managers should revise the mesh-size for the fishery in Lake Victoria.

\section{INTRODUCTION:-}

The Silver Cyprinid, Rastrineobola argentea (Pellegrin, 1904) is locally known as Omena in Kenya, Dagaa in Tanzania and Mukene in Uganda. It is one of the surviving endemic fish species in Lake Victoria (Manyala and Ojuok, 2007). The fish is also found in Lakes Kyoga, Bulera and Ruhondo. The main diet of R. argentea in Lake Victoria has been reported to primarily consist of copepods, cladocerans, rotifers and insects (Yongo et al., 2016). High densities of $R$. argentea are mostly found off shore in deep waters (LVFO, 2011) while the fish prefer shallow littoral habitats as breeding where they use as nursery grounds (Manyala and Ojuok, 2007).

R. argentea fishingis currently the leading commercial fisheries of Lake Victoria comprising $60 \%$ of the total catch, out of which $20 \%$ goes for human consumption while $80 \%$ is processed for animal feed (LVFO, 2012). The fishing of $R$. argentea in Lake Victoriais largely based on the attraction of fish by an artificial light at night and by using seine nets. The minimum net mesh size of $10 \mathrm{~mm}$ on Lake Victoria is allowed by law in Kenya, Tanzania and Uganda for fishing $R$. argentea (LVFO, 2012), though fishers use illegal $5 \mathrm{~mm}$ mesh to increase on their catch. 
There are seasonal variations in catches linked to the lunar cycle. During full moon, the catches are very low due to the reduced power of light attraction and catches are highest during the darkest nights with little or no moon (Ojwang et al., 2014). A closed season for R. argentea is enforced in the Kenyan part of the lake from $1^{\text {st }}$ April to $31^{\text {st }}$ August which appears to be its peak breeding season (Njiru et al., 2005). This has never been implemented adequately since some illegal fishing still occur in some parts of the lake even during the closed season.

There are distinct variations in size at maturity of $R$. argentea from various studies (Okedi, 1973; Wanink, 1988; Manyala et al., 1992; Wandera, 1993). Manyala et al. (1992) found significantly more females than males with an overall sex ratio of 1.00:2.56 (male: female) in Lake Victoria. The fish has been reported to breed throughout the year with peaks between March and June, and December and January (Ojwang et al., 2014). Studies by Manyala and Ojuok (2007) showed that fecundity of $R$. argentea weighing up to $2.8 \mathrm{~g}$ body weight is $1,800-3,500$ eggs. There is an indication that fecundity of $R$. argentea is higher in the Nyanza Gulf compared to Mwanza Gulf for larger specimens above $57 \mathrm{~mm}$ TL (Manyala et al., 1992).

The $R$. argentea stocks in Lake Victoria are facing the effects of intensive fishing, predation, environmental changes and pollution. The increased fishing pressure is attributed to the increase in the number of small seine nets targeting $R$. argentea from 3079 in the year 2012 to 4,137 in 2014. Fishers have also reduced their seine nets below the recommended $10 \mathrm{~mm}$ mesh size thus, adding more pressure to the fishery resource. Environmental changes has really caused disturbances in the littoral zones used by the fish for spawning. Increased predation from Nile perch has been reported to cause a reduction in size at maturity and maximum size attained by $R$. argentea in the lake. Infection by the Cestode Ligula intestinalis has also been reported to impair reproduction and reduce fecundity of $R$. argentea.

$R$. argentea is used as a major input for fishmeal processing based on its relatively higher protein content than other fishes (>50\% crude protein). Its low price, easy divisibility into smaller and cheaper units, and its longer shelf life in the dried form increases its demand for human consumption. The fish also plays a crucial role within the ecosystem of Lake Victoria being one of the main prey species of Nile perch, thus supporting its survival in the lake. However, despite its commercial and ecological importance, there is no up-to-date information on biology of this fish. The present study linked this knowledge gap by investigating on some of its biological aspects including Length-weight relationship, Condition factor, Sex ratio, Gonadal Somatic Index and Size at Maturity of $R$. argentea in the Kenyan waters of Lake Victoria. Such information are useful for the fisheries management. For instance, information on length at maturity will guide the fisheries managers in setting the mesh size that can target adult fish while conserving the juvenile fish.

\section{MATERIALS AND METHODS:-}

Lake Victoria with an area of $68,800 \mathrm{~km}^{2}$ is the second largest freshwater lake in the world. It is shared by Kenya, Uganda and Tanzania in the ratios $6 \%, 45 \%$ and $49 \%$ of the surface area (Johnson et al., 2000). It stretches $412 \mathrm{~km}$ from North to South between $0^{\circ} 30^{\prime} \mathrm{N}$ and $3^{\circ} 12^{\prime} \mathrm{S}$ and $355 \mathrm{~km}$ from West to East between $31^{\circ} 37^{\prime} \mathrm{W}$ and $34^{\circ} 53{ }^{\prime} \mathrm{E}$, and lies across the equator at an altitude of $1135 \mathrm{~m}$ above sea level (Johnson et al., 2000). The lake is relatively shallow, with a maximum depth of $80 \mathrm{~m}$ and an average depth of $40 \mathrm{~m}$. Nyanza gulf is a large inlet from Lake Victoria that extends into Kenya, and it is comparatively shallow, with maximum and average depth of $68 \mathrm{~m}$ and $6 \mathrm{~m}$ respectively.

This study was conducted in the Kenyan waters of Lake Victoria (Fig. 1). The lake was divided into two regions: 1). Nyanza Gulf with sampling stations at Dunga ( $\left.0^{\circ} 08^{\prime} 40.7^{\prime \prime} \mathrm{S}, 34^{\circ} 44^{\prime} 12.4^{\prime \prime} \mathrm{E}\right)$; Ngegu $\left(0^{\circ} 29^{\prime} 25.0^{\prime \prime} \mathrm{S}, 34^{\circ} 30^{\prime} 03.8^{\prime \prime} \mathrm{E}\right)$ 2). Open waters with sampling stations at Honge ( $\left.0^{\circ} 02^{\prime} 37^{\prime \prime} \mathrm{S}, 34^{\circ} 00^{\prime} 48.6^{\prime \prime} \mathrm{E}\right)$; Wichlum $\left(0^{\circ} 14^{\prime} 21.4^{\prime \prime} \mathrm{S}, 34^{\circ} 12^{\prime} 34.3^{\prime \prime} \mathrm{E}\right)$. The fishery at Dunga is shallow (3-4 m) covering the inner Nyanza gulf waters. Ngegu is deep $(8-14 \mathrm{~m})$ and covers the mid Nyanza gulf waters. Wichlum is shallow $(5-7 \mathrm{~m})$ covering the open waters. Honge is deep (16-25 $\mathrm{m})$ and covers the open waters.

Eighty (80) fresh fish were collected monthly from landed commercial catches in each of the four stations between August 2014 and March 2015 (total sample = 2240 fish). Individual fish were measured (Standard Length, SL; Total Length, TL cm) and weighed (0.01g) in the field using an electronic balance (KERN, EMB 200-2). Sub-samples of 840 fish were preserved in $5 \%$ formalin for gonad analysis. In the laboratory each fish was dissected ventrally using scalpel and sexed, then the gonads weighed $(0.01 \mathrm{mg})$ using a sensitive electronic balance (Mettler Toledo, AG204). 


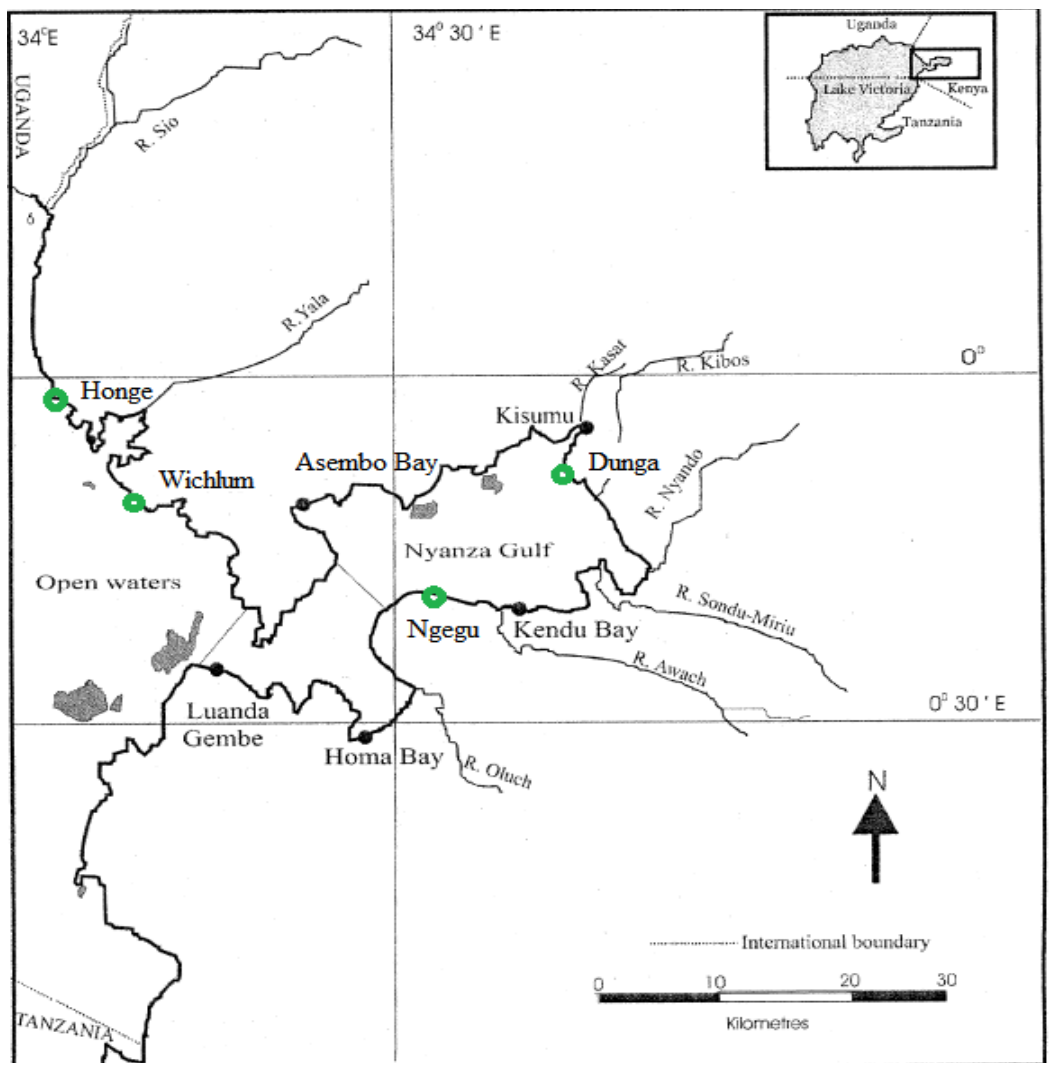

Figure 1: Map of Lake Victoria showing the sampled stations

1. The length-weight relationship was determined using the equations by Karna et al (2012):
$W=a \times T L^{b}$
$\log W=\log a+b \log T L$
(Equation 1)
(Equation 2)

Where $W$ is the weight of the fish $(\mathrm{g}), T L$ is the total length $(\mathrm{cm}), a$ is the intercept and $b$ is the regression coefficient.

2. Relative Condition Factor $\left(\mathrm{K}_{\mathrm{n}}\right)$, was calculated according Lecren (1951):

$$
K_{n}=W /\left(a \times T L^{b}\right)
$$

Where $W$ is the observed weight, $a, T L$ and $b$ are the intercept, total length and regression coefficient.

3. Gonadal Somatic Index was calculated usingthe equation:

$G S I=($ Gonad weight $\times 100) /($ Gonad free body weight $)$

(Equation 4)

4. The length at $50 \%$ maturity $\left(\mathrm{L}_{\mathrm{M} 50}\right)$ was estimated from a logistic curve equations:

$$
\begin{array}{ll}
\operatorname{Ln}\left(\left(1 / P_{L}\right)-1\right)=S_{1}-S_{2} \times L & \text { (Equation 5) } \\
L_{M 50}=S_{1} / S_{2} & \text { (Equation 6) }
\end{array}
$$

Where, $P_{L}$ is the probability of maturity at length $L, S_{I}$ is the intercept and $S_{2}$ is the slope.

Sex and maturity were determined according to Manyala et al. (1992) as described below. Fish in maturity stages I and II were considered immature, while those in stages III-V were considered mature for the purpose of calculating the length at $50 \%$ maturity $\left(\mathrm{L}_{\mathrm{M} 50}\right)$ :

Stage I. Undetermined. Gonads are not yet well formed. Not possible to distinguish sexes

Stage II. Immature:-Testis appears as a thin-threadlike structure covered with fat and anterior tip extends to gill region. The ovary is more flattened, covered with fat and ends into a blunt tip

Stage III. Maturing:-Testes have increased in size and are even rounded. Ovaries are showing eggs and when the ovary is pieced the eggs are held together by the interstitial tissue with many transparent egg structures

Stage IV: Mature almost ready to spawn or spawning:-Testis large and tend towards flattening with some showing folds. Spawning individual may have part of the testis empty with the remaining milt concentrated towards the pore. Ovaries are enlarged with large eggs of almost size. When the ovary is punctured eggs separate easily.

Stage V: Resting:-Testes do not completely loose their milt but grow smaller and appear as seen in stage III. Eggs have been shed and the few remaining are reabsorbed ending in a flat firm structure similar to the immature stage. 
Statistical Analysis:-

Kruskal-Wallis test was used to test variations in condition factor. Chi-square test was used to test the sex ratio. Analysis of Covariance (ANCOVA) was used to test for the slopes of the length weight relationships in relation to sex and stations

RESULTS:-

Length-weight relationship:-

Results for length-weight relationship showed that $R$. argentea experienced positive allometric growth $(b>3)$ in most stations (Fig. 2). The highest value of the regression slope $b$ was recorded in male fish from Dunga (3.40) and the lowest in female fish from Ngegu (2.92). The regression slope $b$ was significantly different between the sexes (ANCOVA: $\mathrm{F}=18.13, \mathrm{p}=0.001$ ) and within the stations (ANCOVA: $\mathrm{F}=10.23, \mathrm{p}=0.032)$. The highest mean $( \pm \mathrm{SE}$ ) standard length $(46.50 \pm 0.20)$ and lowest $(44.10 \pm 0.20)$ were recorded at Honge and Ngegu respectively.
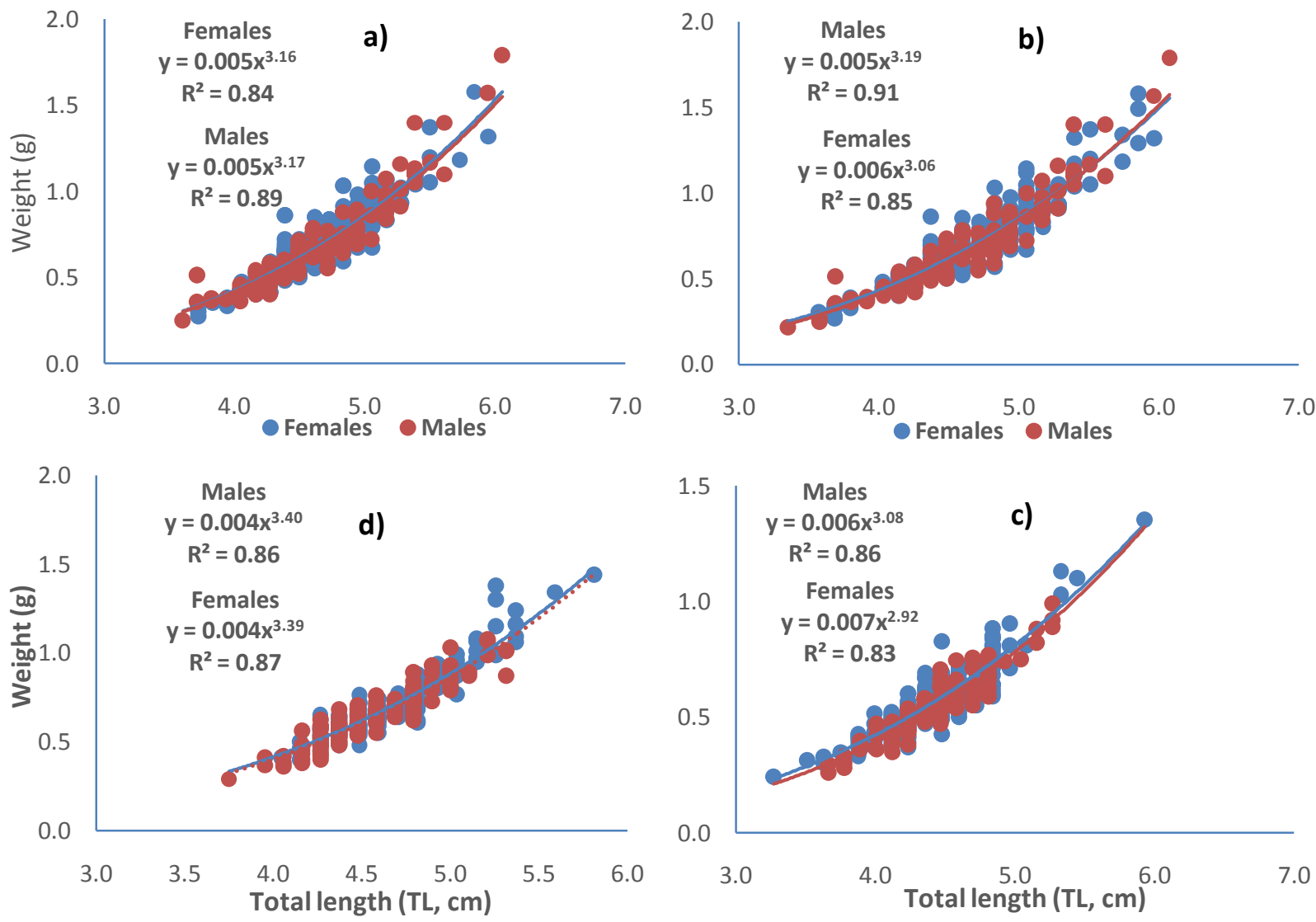

Figure 2: Length- weight relationship of $R$. argentea in Lake Victoria, Kenya. a) Honge, b) Wichlum, c) Ngegu and

\section{Length at $50 \%$ maturity:-}

d) Dunga.

Lengths at $50 \%$ maturity $\left(\mathrm{L}_{\mathrm{M} 50}\right)$ for either sex are presented for each station (Table 1). In male fish, Honge (39.8 mm $\mathrm{SL}$ ) and Ngegu (36.4 mm SL) recorded the highest and lowest $\mathrm{L}_{\mathrm{M} 50}$ respectively, whereas in female fish Dunga (39.1 $\mathrm{mm} \mathrm{SL}$ ) recorded the highest and Ngegu (35.7 $\mathrm{mm} \mathrm{SL)} \mathrm{the} \mathrm{lowest.}$

Table 1: Length at 50\% maturity of $R$. argentea from Lake Victoria, Kenya.

\begin{tabular}{|l|l|l|l|l|}
\hline Station & Ngegu & Honge & Wichlum & Dunga \\
\hline $\mathrm{L}_{\mathrm{M} 50}$ Male (SL, mm) & 36.38 & 39.83 & 38.71 & 38.33 \\
\hline $\mathrm{L}_{\mathrm{M} 50}$ Female (SL, mm) & 35.65 & 38.66 & 38.78 & 42.39 \\
\hline
\end{tabular}




\section{Sex ratio:-}

Numbers and sex ratios for each station and the whole lake are summarized in Table 2. The female fish were significantly dominant than males in nearly all stations, except at Dunga where male fish were dominant. The fish population was dominated by females with an overall male to female ratio of 1.00:1.38. Sex ratio showed that females were significantly more than males and deviated from 1:1 ratio $\left(\chi^{2}=37.12, p<0.001\right)$.

Table 2: Numbers and sex ratio of $R$. argentea from Lake Victoria, Kenya.

\begin{tabular}{|l|l|l|l|l|l|}
\hline Site & Ngegu & Dunga & Wichlum & Honge & Whole lake \\
\hline Males & 117 & 198 & 143 & 151 & 609 \\
\hline Females & 197 & 154 & 232 & 258 & 841 \\
\hline Sex ratio (M: F) & $1.00: 1.68$ & $1.00: 0.78$ & $1.00: 1.62$ & $1.00: 1.71$ & $1.00: 1.38$ \\
\hline
\end{tabular}

\section{Temporal variation in GSI and Relative condition factor:-}

The mean $( \pm \mathrm{SE})$ condition values recorded were 1.096 \pm 0.01 (male) and $1.097 \pm 0.01$ (female) fish, with range values of 0.78-1.59 and 0.77-1.57 respectively. The relative condition factor did not differ significantly between male and female fish (Kruskal Wallis test; $\mathrm{H}=0.03, \mathrm{p}=0.86$ ). The mean $( \pm \mathrm{SE}) \mathrm{GSI}$ values recorded were $1.08 \pm 0.04$ (male) and $6.02 \pm 0.14$ (female) fish. TheGSI ranged between 0.02 and 3.38 or 0.34 and17.39 in male and female fish respectively. Both condition factor and GSI did not differ significantly with the stations and therefore, data from the stations were pooled to represent Nyanza Gulf and open water sections. $R$. argentea showed peak condition and GSI in September and February, and October and March for open waters and Nyanza Gulf respectively (Fig. 3). There was no R. argentea fishing in the Nyanza Gulf during August and November due to bad weather.
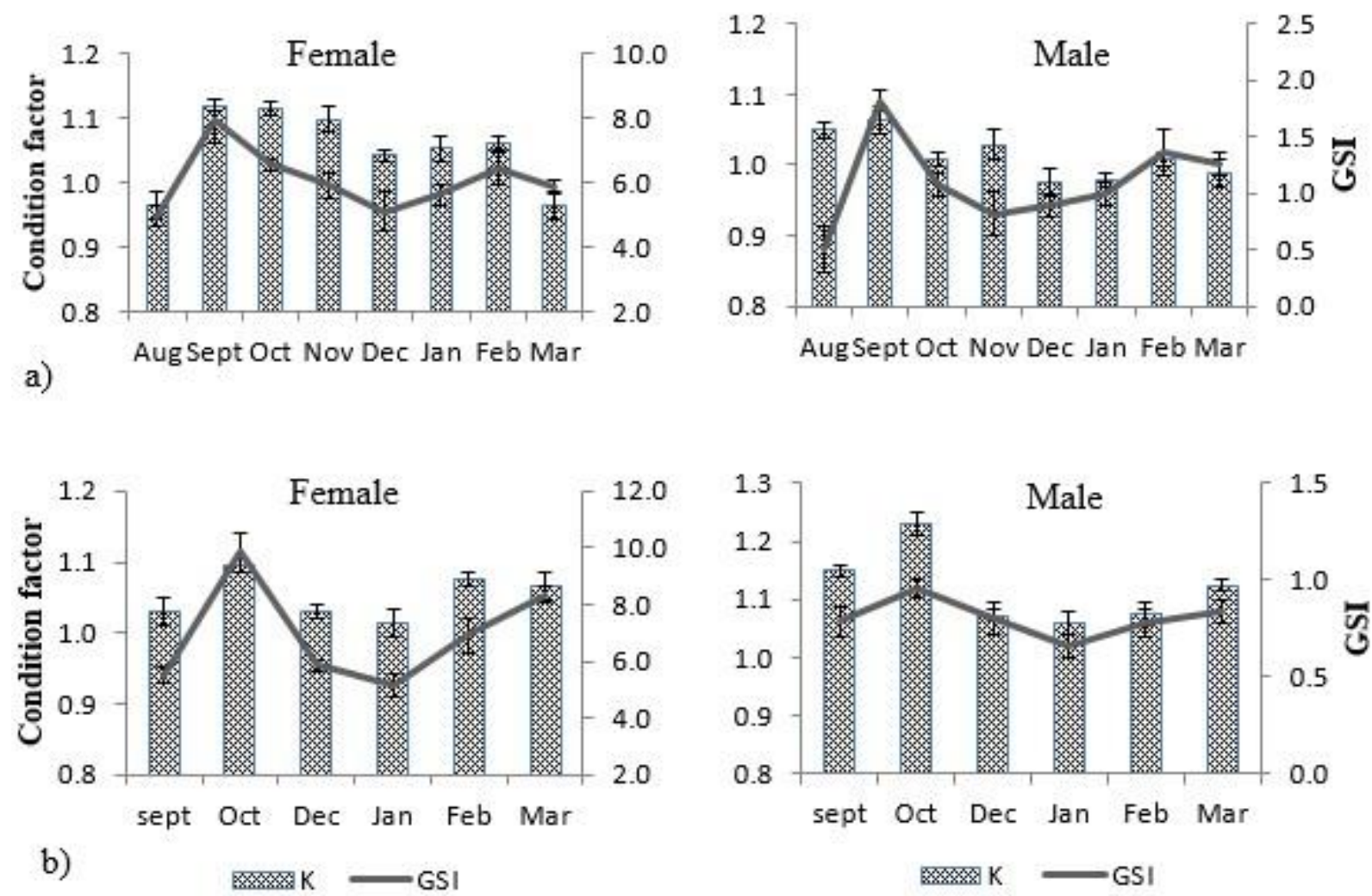

Figure 3: Monthly variation in condition factor (K) and Gonadal Somatic Index (GSI) of male and female $R$. argentea from a) open waters b) Nyanza Gulf Lake Victoria, Kenya during the study. Vertical lines (mean \pm SE). 


\section{DISCUSSION:-}

The fish showed a positive allometric growth pattern ( $b>3)$. This implies that it becomes relatively deeper-bodied as it increases in length (Riedel et al., 2007). According to Arslan et al (2004), the $b$ value can be used as an indicator of food intake and growth pattern, and may differ according to biotic and abiotic factors, food availability and habitat type.The $R$. argentea caught from the open waters of Lake Victoria had a slightly higher mean standard length than those caught from the Nyanza Gulf. This could be because fishers in the open waters fish in the deeper waters where they catch adult fish, unlike in the Gulf where fishing is concentrated mainly in the littoral areas that are known as nursery and breeding grounds. The study showed a reduction in length at maturity for both male and female fish especially at Ngegu. Wandera (1993) determined the size at maturity of $R$. argentea at Pilkington Bay in the Ugandan waters of Lake Victoria to be 40-41 mm SL for male and 43-44 mm SL for female fish. Manyala et al. (1992) estimated the size at massive maturity of $R$. argentea at $34 \mathrm{~mm}$ SL for male and $36 \mathrm{~mm}$ SL for female fish in the Kenyan section of Lake Victoria.The great reduction in length at maturity of $R$. argentea at Ngegu station could beattributed to the rampant use of illegal seine nets less than $10 \mathrm{~mm}$ mesh in this particular fishing ground (Personal observation). According to Manyala and Ojuok (2007), R. argentea in Lake Victoria hasreduced its size at maturity as well as its maximum size in response to increased predation and fishing. Length at maturity in some fish species, such as tilapias, may decline in response to adverse environmental conditions (Welcomme, 2001). The intensive fishing in this case could be justified by the frame survey results in which the total number of small seine nets targeting $R$. argentea in Lake Victoria increased from 3,079 in the year 2012 to 4,137 in 2014.

The results indicated that females were significantly more than males. The dominance of female over male $R$. argentea revealed in the present study agrees with Manyala et al. (1992) in the Kenyan waters of Lake Victoria. The results are also in agreement with Okedi (1973) who reported a sex ratio of 1.00: 1.56 (male to female) in the Ugandan waters of Lake Victoria.The dominance of females together with high fecundity could help the fishery withstand intensive fishing in Lake Victoria. However, Usman et al. (2013) reported a sex ratio of 1.00: 1.25 (male to female) in Sardinella sindensis from Karachi coast in Pakistan, but was not significantly different from the expected theoretically 1:1 ratio.Populations of $R$. argentea showed peak condition and GSI during the months of September/February and October/March for open waters and Nyanza Gulf respectively. These results are in agreement with Ojwang et al. (2014), but differ from Wandera (1999), who reported the fish showing peak condition in the drier months of August and December-January, and minimal breeding in the rainy months of AprilMay and October-November. The fish showed mean condition with values above 1, which implied that it had attained a better condition. This could be due to abundance of food within the lake as this has been shown to improve the condition of fish (Khallaf et al., 2003). The fish condition is also dependent on the season, sex and life stages.

\section{CONCLUSIONS:-}

$R$. argentea exhibited positive allometric growth and therefore studies on this fish should not assume isometric growthpattern. The fish has reduced in length at maturity and therefore the fisheries managers should revise the mesh-size for the fishery in Lake Victoria.

\section{ACKNOWLEDGEMENTS:-}

This research was funded by Lake Victoria Comprehensive Ecosystem \& Aquatic Environment Research Development (LAVICORD) Project and the Core-to-Core Program by Japan Society for the Promotion of Science (JSPS).We wish to thank the Africa research stationsof Nagasaki University for the good collaboration in undertaking the research

\section{REFERENCES:-}

1. Arslan, M., Yildırım, A and Bektas, S. (2004). Length-weight relationship of brown trout, Salmo trutta (L.), inhabiting Kan Stream, Çoruh basin, north-eastern Turkey. Turkish Journal of Fisheries and Aquatic Sciences. 48, 45-48.

2. Johnson, T.C, Kelts, K and Odada, E. (2000). The Holocene history of Lake Victoria. Ambio.29 (10): 2-14.

3. Karna, S.K., Sahoo, D., Panda, S., Vihar, V., Bhaban, M and Nagar, S. (2012). Length -Weight Relationship, Growth estimation and Length at maturity of Etroplus suratensis in Chilika Lagoon, Orissa, India. International Journal of Environmental Sciences. 2, 1257- 1267.

4. Khallaf, E, Galal, M and Athuman, M. (2003). The biology of Oreochromis niloticus in a polluted canal. Ecotoxicology. 12: 405-416. 
5. Le Cren, E. D. (1951). The length-weight relationship and seasonal cycle in gonad weight and condition in the perch (Perca avescens). Journal of Animal Ecology. 20: 201-219.

6. LVFO. (2011). Technical Report: Stock Assessment Regional Working Group, 2011 November 22-25, Ridar Hotel, Seeta, Uganda.

7. LVFO. (2012). Manual for Processing and Marketing of Small-Sized Pelagics, Popular Version, LVFO, Jinja, Uganda. Technical Document, 12 (42): 8-9.

8. Manyala, J.O., Nyawade, C.O and Rabuor, C.O. (1992). The Dagaa (Rastrineobola argentea (Pellegrin) fishery in the Kenyan waters of Lake Victoria: A national review and proposal for future research', in Mannini P. (ed.) The Lake Victoria Dagaa (Rastrineobola argentea): Report on the First Meeting of the Working Group on Lake Victoria Rastrineobola argentea, Kisumu, Kenya. 18-35.

9. Manyala, J.O. and Ojuok, J.E. (2007). Survival of the Lake Victoria Rastrineobola argentea in a rapidly changing environment: Biotic and abiotic interactions. Aquatic Ecosystem Health and Management. 10 (4): 407-415.

10. Njiru, M., Budeba, Y and Wandera, S.B. (2005). Reproduction and growth of commercially important fish species, in The State of the Fisheries Resources of Lake Victoria and their Management, LVFO Secretariat, Jinja, Uganda. 85-96.

11. Ojwang, W.O., Ojuok, J.E., Nyamweya, C., Agembe, C., Owili, M., Yongo, E and Wakwabi, O. (2014). The intriguing dynamics of Rastrineobola argentea fishery in the Kenyan waters of Lake Victoria. Aquatic Ecosystem Health and Management. 17 (1): 80-89.

12. Okedi, J. (1973). Preliminary observations on Engrauli cyprissrgenous from Lake Victoria, EAFFRO annual report 1973.

13. Riedel, R., Caskey, L.M and Hurlbert, S.H. (2007). Length-weight relations and growth rates of dominant fishes of the Salton Sea: implications for predation by fish-eating birds. Lake and Reservoir Management. 23: 528535.

14. Usman Ali Hashmi, M, Amtyaz, Zaheer Khan, M. and Atiqullah Khan, M. (2013). Studies on Gonadosomatic Index (GSI) and sex ratio of Sand sardine fish, Sardinella sindensis (Day, 1878) (family: Clupeidae) of Karachi coast, Pakistan. International Journal of Biological Research. 1 (2): 34-40.

15. Wandera, S.B. (1993). The biology, ecology and fishery of Mukene, Rastrineobola argentea. In: FIRI/IDRC Workshop on Environment, Fisheries and Socio-economic changes in the Lake Victoria Basin, 1993 November 15-20. Jinja, Uganda.

16. Wandera, S.B. (1999). Reproductive biology of Rastrineobola argentea (Pellegrin) in the northern waters of Lake Victoria', in Report on Fourth FIDAWOG Workshop held at Kisumu, 16 to 20 August 1999. Jinja, Uganda, LVFRP Technical Document, 7:184-191.

17. Wanink, J.H. (1988). Recent changes in the zooplanktivorous/insectivorous fish community of the Mwanza Gulf', Report of the Haplochromis Ecology Survey Team (HEST) and the Tanzania Fisheries Research Institute (TAFIRI) operating in Lake Victoria, Leiden, The Netherlands, 45.

18. Welcomme, R.L. (2001). Inland Fisheries: Ecology and Management, United Kingdom: Gray Publishing in Tunbridge Wells, Kent, 45-50.

19. Yongo, E., Manyala J.O., Kito, K., Matsushita, Y., Outa, N.O andNjiru, J.M. (2016). Diet of Silver Cyprinid, Rastrineobola argentea in Lake Victoria, Kenya. International Journal of Advanced Research, 4 (4): $144-149$. 